\title{
Sexualities
}

\section{Queer Theory from the South: A Contribution to the Critique of Sexual Democracy}

\begin{tabular}{|c|c|}
\hline Journal: & SEXUALITIES \\
\hline Manuscript ID & SEXU-18-0166.R1 \\
\hline Manuscript Type: & Article \\
\hline Keywords: & $\begin{array}{l}\text { sexual democracy, queer theory, decoloniality, southern epistemologies, } \\
\text { South Africa }\end{array}$ \\
\hline Abstract: & $\begin{array}{l}\text { This essay draws on the turn to southern epistemologies in social theory } \\
\text { as a provocation for rethinking the problems and possibilities of 'sexual } \\
\text { democracy.' First, I situate 'queer theory from the South' in relation to } \\
\text { ongoing queer and decolonial critiques of sexual democracy. I then turn } \\
\text { to the case of South Africa, examining ubuntu as an alternative } \\
\text { framework for developing a sexual politics that can negotiate between } \\
\text { the Euro-American liberal rights frames and indigenous values. Finally, I } \\
\text { conclude by illustrating this with the work of a Zulu lesbian sangoma, } \\
\text { whose theory and practice offers a vision of decolonizing erotic justice. }\end{array}$ \\
\hline
\end{tabular}

\section{SCHOLARONE Manuscripts}




\section{Queer Theory from the South: A Contribution to the Critique of Sexual Democracy}

Abstract: This essay draws on the turn to southern epistemologies in social theory as a provocation for rethinking the problems and possibilities of 'sexual democracy.' First, I situate 'queer theory from the South' in relation to ongoing queer and decolonial critiques of sexual democracy. I then turn to the case of South Africa, examining ubuntu as an alternative framework for developing a sexual politics that can negotiate between the Euro-American liberal rights frames and indigenous values. Finally, I conclude by illustrating this with the work of a Zulu lesbian sangoma, whose theory and practice offers a vision of decolonizing erotic justice.

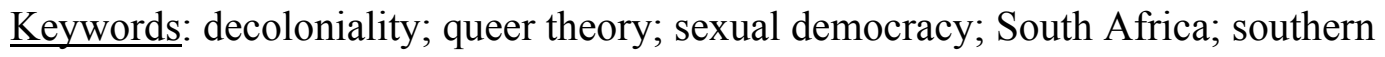
epistemologies 


\section{Queer theory from the South A contribution to the critique of sexual democracy ${ }^{i}$}

Euro-America, as anthropologists Jean and John Comaroff (2012) have recently suggested, is evolving toward the global South. Over the past decade, conditions long considered characteristic of the 'developing' world - economic precarity and a growing underclass, state austerity and privatization, populist uprisings and ethno-cultural tribalism, fraudulent elections and rampant government corruption, terrorism and environmental destruction - have become the 'grim New Normal' throughout the global North. For the Comaroffs, if it is true that life for many in the global North increasingly resembles that which has come to be associated with the South, then perhaps it is to the South that we must look for ways of thinking about and responding to our present condition. 'What if we posit,' they ask (2012: 1), 'that, in the present moment, it is the global South that affords privileged insight into the workings of the world at large? That it is from here that our empirical grasp of its lineaments, and our theory-work in accounting for them, is and ought to be coming, at least in significant part?' This is a prescriptive southward evolution that the Comaroffs name 'theory from the South.' While the South has long functioned as a site of resource extraction for the production of industrial and intellectual value in the North, massive economic, geopolitical, and demographic shifts are redrawing colonial cartographies of centers and peripheries, 'relocating southward - and, of course, eastward as well-some of the most innovative and energetic modes of producing value' (Comaroff and Comaroff, 2012: 7). Theory from the South therefore constitutes a profound shift in the geopolitics of knowledge that turns to the South not as raw data for Euro-American theorization, but as 'rich sites of new knowledges and ways of knowing-and-being... that have the capacity to inform and transform theory in the North, to subvert its universalisms in order to rewrite them in a different, less provincial register' (Comaroff and Comaroff, 2012: 49). In this respect, theory from the South facilitates a reconceptualization of democracy, cosmopolitanism, secularism, humanism, law and rights, citizenship, sovereignty, and many other issues that Euro-American critical theorists have recognized as urgently needed to confront the many crises that beset today's world (see Cornell, 2008; De Cauwer, 2018).

In this essay, I use the Comaroffs' Theory from the South as a starting point for rethinking sexual democracy. Over the past three decades, the global politics of sexuality have been increasingly articulated through the terms and instruments of liberal democracy, a model that has proven quite successful at securing recognition and protections on the basis of 'sexual orientation and gender identity' at the national and international levels. While appealing to a more inclusive democracy, the incorporation of sexuality into immigration and asylum policies, foreign policy, development and aid initiatives, human rights resolutions, and other political mechanisms systematically encodes certain Euro-American sexual values as synonymous with the values of 'democracy' itself, thereby positioning other sexual value systems - particularly those of Africa and Islam — as inherently anti-democratic (Giametta, 2017; Luibhéid, 2002; Puar, 2017, Richardson, 2017). The complicity of 'sexual democracy' in consolidating racist, xenophobic, and imperialist projects raises serious questions about its continued viability as a framework for sexual emancipation (Fassin, 2010; Sabsay, 2016). Indeed, far from securing global sexual freedom, the virulent opposition this model has provoked throughout Africa and the Middle East has led to an increase in persecution of even 'indigenous' forms of queerness, which are now interpreted through the frame of 'western' LGBT identities (Onapao and Isike, 2016). This often puts African and Muslim queers, in both the global North and South, in the 
impossible position of having to choose between making their sexualities legible in EuroAmerican terms in order to combat repression and violence or resisting imperialist logics that ultimately seek to obliterate their own cultural and spiritual values. If sexuality is indeed emerging as the fundamental 'cultural fault line' dividing the west from the rest (Inglehart and Norris, 2003), it becomes one of the issues that most urgently calls for modes of theorization capable of negotiating between competing cultural values in a way that opens even our most ostensibly 'universal' ideals to reconceptualization vis-à-vis other modes of being and thinking. As Judith Butler (2008: 20) puts it: 'The possibility of a political framework that opens our ideas of cultural norms to contestation and dynamism within a global frame would surely be one way to begin to think a politics that re-engages sexual freedom in the context of allied struggles against racism, nationalism, and the persecution of national and religious minorities.'

In this spirit, what follows contributes to queering theory from the South by rethinking sexual democracy through South Africa and, in particular, the 'philopraxis' of ubuntu. South Africa is an indispensible site to such a project because it is a microcosm for many of the challenges posed by sexual democracy on a global scale; indeed, while most literature on sexual democracy focuses on the United States, France, and the Netherlands, South Africa was in fact one of the world's first 'sexual democracies' and has been dealing with its associated challenges for over three decades now. ${ }^{\text {ii }}$ By the standards of liberal democracy, South Africa has a record on sexuality that rivals the vast majority of Euro-American states: the first nation in the world to prohibit discrimination on the basis of sexual orientation as a matter of constitutional law (1994), the fifth nation (after only the Netherlands, Belgium, Canada, and Spain) to recognize same-sex marriage (2006), the sponsor of the first resolution passed by the UN Human Rights Council on sexual orientation and gender identity (2011). On the other hand, like many postcolonial nations, South Africa struggles with widespread beliefs that homosexuality is an 'unAfrican' colonial imposition and extremely high levels of homophobic violence (including horrific 'corrective rapes' of lesbians), making its progressive legislation a legal formality for most Black and coloured queers, especially those living in the massive informal settlements. This is all in addition to the more general challenges South Africa faces as an economic powerhouse with enormous wealth disparities, as an extremely multicultural society through both successive waves of settler colonization and increasing intracontinental immigration, and as a postcolonial constitutional democracy in which the majority of the Black population lives under customary law in the rural areas and townships, leading to frequent clashes of authority between the state and 'traditional' leaders.

In grappling with the contradictions of sexual democracy, then, South Africa certainly gives the lie to the Eurocentric logic that postcolonial theorist Dipesh Chakrabarty (2000: 6) has famously characterized as 'first in the West, and then elsewhere.' Indeed, it is South Africa's long struggle with all the promises and failures of sexual democracy that makes it so invaluable - as Brenna Munro (2012: ix) phrases it in her beautiful account of sexuality and the South African struggle for freedom - for all of us who 'continue to struggle for radical democracy on queer terms in the global North.' By rethinking sexual democracy from and with South Africa in this way, queer theory from the South thus takes up Maya Mikdashi and Jasbir Puar's (2016: 216-7) call for 'a politics in queer theory that works to displace the United States as the prehensive force for everyone else's future,' that decenters the global North as the 'arbiter and funnel for the legibility of theory elsewhere, and the arbiter of what is to come, to be learned or apprehended.' Indeed, and especially given the growing crisis in the norms and institutions of Euro-American liberal democracy in which sexual politics have largely been framed, the future 
possibilities of erotic justice more than ever depend on theorists and policy makers in the global North learning from a country like South Africa. As a brief contribution to this project, the focus of this essay will be to provide neither a substantive theorization of the highly complex development of 'sexual democracy' in South Africa nor a review of queer theory from the South African context, but a speculation on how a particular Southern African value, ubuntu - when thought in terms of the Comaroffs' call for a reframing of political theory from the vantage of the South - might offer a point of departure for a queer-decolonial reformulation of the global project of sexual democracy.

\section{Queer theory from the South}

As the reigning conviction that there are no alternatives to Euro-American neoliberalism is steadily losing its hegemony worldwide, many social and political theorists have called for a new intellectual engagement with the South (Bhambra, 2014; Comaroff and Comaroff, 2012; Connell, 2007; de Sousa Santos, 2014). Theory from the South is all the more urgent in light of what Boaventura de Sousa Santos (2014: 19) diagnoses as an 'exhaustion' haunting EuroAmerican critical theory that 'manifests itself in a peculiar and diffuse uneasiness expressed in multiple ways: irrelevance, inadequacy, impotence, stagnation, paralysis' and, one might add, pessimism. To revivify a critical theory capable of confronting today's challenges, let alone to reach any affirmative imagination of a collective 'buen vivir' entails scholars in the global North learning to know the world differently. This calls for a profound epistemic shift in what we can know for, as Kant (1998: 677) famously demonstrated at the birth of critical philosophy, the question of what we can know is inextricably connected to the questions of what we should do and for what we might hope. Such transformations in knowledge are what de Sousa Santos has gathered under the aegis of 'epistemologies of the South,' which challenge the Eurocentric conditions of knowledge production by valuing the forms and practices of knowledge that have survived in the face of epistemic colonization. In this way, and although not central to the Comaroffs' own formulation, theory from the South is part of a project of decolonization. As social theorist Aníbal Quijano argues (2010), the Euro-American paradigm of rationality is a logic of 'coloniality' that has structured the global patterns of power since the conquest of the Americas insofar as it is the purported universality of European 'Reason' that provides the epistemic legitimation for Euro-American hegemony. Thus, 'epistemological decolonization as decoloniality' writes Quijano (2010: 31), 'is needed to clear the way for new intercultural communication, for an interchange of experiences and meanings, as the basis for another rationality which may legitimately pretend to some universality.' This 'other' rationality in no way amounts to a renunciation of the Euro-American critical tradition, but rather arises through the cultivation of a planetary 'ecology of knowledges' (de Sousa Santos, 2014: 42) through a decolonization of social and political thought and practice.

Because the global politics of sexuality provoke an especially intense confrontation between the false universality of Euro-American rationality and decolonial challenges, its theorization calls for such an epistemological ecology in a way that is particularly acute. In her critique of the 'political imaginary' of sexual democracy, Leticia Sabsay (2016: 158) suggests that 'a queer perspective, in dialogue with a decolonial approach could expand the signifiers of sexuality against sovereignty and toward more democratic solidarities.' After all, queer theory is renowned for its deconstructive approach to hegemonic sexual definitions and, certainly, its Foucauldian conceptualization of sexuality as a technology of power-knowledge that reifies diverse corporeal and erotic practices in the form of coherent sexual identities and categories 
enables a tracking of the coloniality of power within the epistemology that frames global sexual politics. This epistemology, as early queer theorist Eve Kosofsky Sedgwick (1990: 2) described it, emerged in European modernity as a 'world-mapping' that leaves 'no place in the culture exempt' from a binarized configuration of homo/heterosexuality replete with definitional incoherencies. And as many decolonial feminist and queer thinkers have demonstrated, this 'world-mapping' of modern sexuality is anything but metaphorical. Critiquing Quijano's seminal formulation, María Lugones (2007) demonstrates that gender and sexuality were not merely shaped by the 'coloniality of power,' but were modes through which the very patterns of coloniality were established as the European system of binarized sexuality and gender was imposed on indigenous arrangements of bodies, pleasures, kinship and reproduction in Africa and the Americas. The coloniality of power is therefore maintained in a global politics of sexuality that, as Joseph Massad (2007: 163) puts it, 'assumes prediscursively that homosexuals, gays, and lesbians are universal categories that exist everywhere in the world,' when it is this very politics that produces these categories and identities 'where they do not exist and repress[es] same-sex desires and practices that refuse to be assimilated into its sexual epistemology.' In their queer analyses of colonization, scholars such as Greg Thomas (2007) and Scott Morgensen (2011) have shown that this sexual epistemology operates in such a way that for anything to become legible as sexuality — even as 'queer' - it must do so within a field of intelligibility that upholds white supremacy and settler colonization through the continued erasure of both other erotic practices and the relations of power that keep the epistemic frame of 'sexuality' firmly in place, even when 'queering' it. In revealing the epistemology of sexuality as a fundamental axis of coloniality, these theorists clear the way for a queer-decolonial 'epistemological reconstitution' of sexual politics.

Displacing the hegemony of the Euro-American conceptualization of sexuality, however, will require more than an epistemological reconstitution. Indeed, because, as decolonial theorist Nelson Maldonado-Torres (2003) has argued, coloniality structures not only relations of power and thought but also being itself, decolonization necessarily involves an ontological dimension. In the process of colonization, indigenous ontologies - which were not viewed as different ways of being and knowing the world, but as false belief systems - were destroyed so as to impose that of the European colonizers. This is why Eduardo Viveiros de Castro (2015) has called for an anthropology that seeks to move beyond the ethnographic study of different 'world-views' (which presumes a singular world) to the study of different conceptual worlds as 'the permanent decolonization of thought.' The work in what has recently been called the 'ontological turn' (Holbraad and Pedersen, 2017) challenges what Viveiros de Castro (2015: 54) refers to as the 'absolute ontological monarchy' of Euro-American thought-i.e., the assumption that the reality to which all thought ultimately refers is the same and is, moreover, isomorphic with reality as described by Euro-American philosophy and science- which 'derealizes' all non-EuroAmerican thought. One of the central moves of this work is thus to replace the multiculturalist thesis that there is but one nature that is subject to many cultural 'interpretations' with the 'multinaturalist' thesis that there are in fact many natures to which human culture refers. As such, 'cultural' differences reflect not merely differences in representation but differences in the very nature of reality. Taking this intervention seriously would obviously have profound implications for queer theory, which has long been premised on a denaturalization of sexuality. It is because such a mononaturalist ontology of sexuality ultimately underlies these queer efforts at denaturalization that, as Greg Thomas (2007: 23) puts it, 'the white world is always renaturalized as a universal standard of human civilization and its erotic practice.' This means that the Euro- 
American framework must be challenged not only by 'denaturalizing' particular cultural modes of sexuality but by destabilizing the very ontological monarchy of 'Sex' over all erotic realities. As Sabsay (2016: 149) writes, 'Only by focusing the critique on the conditions of intelligibility that allow for the emergence of these identities, and by further questioning the link of "the sexual" with identities as a whole, would it be possible to challenge the universalization of Western sexual epistemology.' Queer-decolonial theory would therefore have to go beyond what Kath Weston (1993: 341) referred to as a mere 'ethnocartography' of alternative or 'queer' sexualities - which maintains and reifies the mono-ontology of sexuality - to thinking other erotic ontologies or what Thomas Hendriks (2018: 858) names 'erotologies.' Sexual democracy, then, cannot overcome its limits through what Jasbir Puar (2017: 18) calls an 'epistemological corrective' that would aspire to universality through the incorporation of all 'other' erotic practices, but must open itself to a contestation arising from the very 'ontological irreducibility' of these practices. As I will argue in the next section, however, the critique of sexual democracy entails not only a thinking of other erotic ontologies but of other ontological frameworks for the negotiation between these erotologies. This is because the forms of politics theorized by the leading thinkers of the ontological turn — a 'war of worlds' (Viveiros de Castro, 2015) or the philosopher as 'diplomat' (Latour, 2002) — maintain an ontology of relations as intrinsically antagonistic in a way that African ontologies call into question.

In addition to a queer-decolonial critique of the Euro-American onto-epistemology of sexual democracy, queer theory from the South is also a response to an exhaustion in queer theory of the sort that the Comaroffs and de Sousa Santos have diagnosed within Euro-American critical theory at large. Over the past decade, there has been a growing sense of uneasiness with many of queer theory's central concepts and methods: its attachment to anti-normativity and transgression, its focus on representation and performance, its reliance on a Eurocentric humanist subject, to name but a few (see Cornell and Seely, 2016; Luciano and Chen, 2015; Puar, 2007; Penney, 2014; Wiegman and Wilson, 2015). To my mind, however, many of the recent trends in queer theory - post-humanism, queer negativity, and the turn to affect - often contribute less to what de Sousa Santos (2014: 20) calls 'convincing, widely shared, powerful critical theories... that give rise to effective and profound transformative practices' and more to the continued 'shrinking of the emancipatory political imagination.' Following the project of theory from the South as outlined by the Comaroffs, de Sousa Santos and others, I think that it is within the global South that some of the most promising possibilities for revitalizing queer theory can be located, by providing an occasion to rethink entrenched assumptions about the relationships between sexuality, multiculturalism, secularism, the state, neoliberal capitalism, and the ideals of freedom. If theory can be defined as a praxis 'whose object it is to arrive at a principled sense of the connection between what it is that constitutes the lived world and how that world is affectively and cognitively experienced, acted upon, inhabited by sentient human subjects' (Comaroff and Comaroff, 2012: 48-9), then the point of queer theory from the South is not to certify that Queer Theory exists in the global South but to learn from and with the modes of concrete abstraction that queers in the global South have developed for negotiating their erotic lives. ${ }^{\text {iii }}$ It is this learning from and with the South that distinguishes such a project from the forms of comparativism or academic imperialism that are critiqued by transnational feminist and queer theorists such as Puar and Mikdashi. Rather than superficial 'add and stir' approaches or postmodern relativisms that ultimately serve to reify the hegemonic geographies of reason, theory from the South would consist of what Chandra Talpade Mohanty (2003: 57) has described as 'ways of making connections and asking better questions' out of solidarity in a praxis of alter- 
globalization. In this respect, queer theory from the South as formulated here differs from queer African studies or African queer studies that focus on the particularities of the African contextas necessary and important as such work is - by seeking to rethink the global realities and possibilities of sexual democracy from and with South Africa.

\section{Harmonizing values, renegotiating universality: the philopraxis of $\boldsymbol{U b u n t u}$}

While queer theory from the South offers a way of analyzing sexual categories and identities as especially intense transfer points for the coloniality of power, as well as contributes to a shift in the geopolitics of knowledge that follows the global South in rethinking sexual politics, a queerdecolonial critique of sexual democracy cannot stop at a deconstruction of the Euro-American onto-epistemology of 'sexuality' but must also rethink the ideals of freedom and justice that the project of sexual democracy promises. At a time of horrific violence and inequalities of world historical proportions, and at a time when democratic ideals and institutions have never been more under attack throughout the world, it is as necessary to insist on these ideals as it is to reconceptualize them. Although, as feminist theorists such as Judith Butler (2000) and Saba Mahmood (2005) have argued, all appeals to universal values — including 'freedom' — are bound up with both cultural and linguistic particularities as well as normative assumptions that belie their universality, this does not negate the universal aspirations that animate social and political movements. The task of theorizing transnational and transcultural struggles is therefore neither to relinquish universality in the name of particularity nor to render the universal out of the particular, but, in Butler's (2000: 163) words, 'to adjudicate between competing notions of universality.' Such a project would require going beyond the provincialization of Euro-American ontology through engagement with other ontologies in order to rethink the possible modes of negotiation between these different conceptual worlds in the cultivation of universal justice. Such negotiation is, following legal philosopher Drucilla Cornell (2014: 128), an 'ethical demand' entailed within the universal ideals that necessarily animate any collective struggle for justice. For Cornell, this demand includes a 'call to judgment' which recognizes both that other 'intellectual heritages' offer competing notions of freedom, justice, and other supposedly universal values and that when such values are taken seriously as universals, we might find them to be better ways of thinking and articulating our own values. To quote Cornell (2014: 129):

The call to judgment recognizes that there is a complex terrain of competing universals, that if we actually engage in that terrain...then we may be called to change and revise our own ideals, as we engage with the universals of others and other universals. Only then are we taking seriously the idea that other cultures, or what I am calling intellectual

heritages, offer universal justifications that put a demand on us to both translate them and to engage them in such a way that we are open to a shift and challenge to the hegemony of Eurocentric philosophy.

As exemplified by Cornell's recent rethinking of her own early work vis-a-vis African philosophy, the project of transcultural and transnational solidarity requires the effort to actually learn other values and ideals - studying them with as much seriousness as we have given to Kant, Marx, and Rawls - and of finding ways of negotiating between different articulations of universality.

In this light, the remainder of this essay will examine the significance of the African philosophy of ubuntu in rethinking sexual democracy, as it offers both competing notions of freedom and justice as well as an alternative framework for negotiating competing values. As with the Euro-American onto-epistemology of 'sexuality,' the politics of sexual democracy are 
conceptualized in terms adopted from modern Euro-American liberal philosophies that operate on the basis of a possessive individualism that grants ontological privilege to the abstract, atomistic subject over the social and relational context (see Richardson, 2017; Sabsay, 2016). In this framework, 'justice' is secured through the recognition of rights that belong to the individual subject, while 'freedom' is ineluctably bound up with notions of autonomy - as the individual subject's capacity for self-realization, as the lack of constraint by external forces, or, in the case of neoliberalism, as the maximization of personal choice - that require a move away from 'traditional' or 'cultural' obligations and values. While queer theory is critical of the liberal parameters of mainstream articulations of sexual democracy, Mahmood (2005) and Puar (2007) have shown that the (neo)liberal ideal of the autonomous subject is maintained in its emphasis on the subject's resistance to or transgression of social norms and obligations. In ubuntu, on the other hand, there is a distinctly different relationship between freedom and obligation at work, which will have profound consequences for the conceptualization of sexual ethics and politics. The turn to ubuntu here joins a recent move in Euro-American feminist and queer theory toward more relational and affective ontologies capable of thinking beyond the liberal antagonism between the autonomous individual and the social. And yet, as the Comaroffs (2012: 64) point out, this is another example of how theory from the South anticipates Euro-American theory, for 'had Euro-theory known a little more of Africa...perhaps the idea of a more complex notion of human personhood, one grounded in a multidimensional space-time, might have commended itself a long time ago.' This rejoinder is significant not only to temper the pretentions to 'newness' in some of this Euro-American literature but because Africans have, of necessity, spent centuries developing ethics and politics that syncretize liberal ontologies of the individual with relational ontologies in ways from which we have much yet to learn.

Popularized (and commodified) in recent years as a kind of 'African humanism,' ubuntu is both the 'fundamental ontological and epistemological category in the African thought of the Bantu-speaking people' (Ramose, 2003: 270) as well as a political ethic forged in the decolonial, anti-apartheid, and ongoing counter-hegemonic struggles in Zimbabwe and South Africa. Often accompanied by its Sotho-Tswana cognate botho, ubuntu is a compound word in the Nguni language group formed by the prefix $u b u$, which refers to Being in general, and the suffix -ntu which refers to particular beings. Because Being $(u b u)$ is characterized by perpetual becoming and unfragmented wholeness, it depends on the language and thought of humans to give it the concrete forms (-ntu) through which it can be known, although these forms remain ontologically inseparable from Being itself. Analogous to ubuntu, the concept of the human being, umuntu, is a compound formed by humanity in general (umu-) and concrete people (-ntu). And as ubuntu implies both the unity of 'Being-becoming' and the multiplicity of forms this becoming takes, umuntu highlights the inextricable bond between the individual person and all other people. This notion is expressed in the famous maxim umuntu ngamantu nga bantu, which can be roughly translated as 'a person is a person only through other people.' One's personhood therefore does not come merely from the ontological fact of being human $(u m u)$; rather, one must give this being concrete expression in relations with others. 'In other words,' writes philosopher Magobe Ramose (2003: 272), 'be-ing human is not enough. One is enjoined, yes, commanded as it were, to actually become a human being. What is decisive then is to prove oneself to be the embodiment of $u b u-n t u$ because the fundamental ethical, social, and legal judgment of human worth and human conduct is based upon $u b u$-ntu.' Umuntu and ubuntu thus form what Ramose calls an 'indissociable coupl[e],' as concrete human activity expresses both the whole of Being and of humanity. Because of this onto-epistemological inseparability of $n t u$ from both $u b u$ and 
$u m u$, a person cannot not participate in the ongoing, collective activity of Being and of humanity. This is why, according to Ramose (2003: 276), there is a common Bantu understanding of 'being as musical harmony': one cannot be a merely passive spectator of this cosmic dance and thus ethical activity is that which amplifies the 'harmony of be-ing.'

While $u$ buntu, like other African 'communalist' philosophies, is often criticized by EuroAmerican social and political theorists for subsuming the individual in the community, each person actually functions as an active nodal point in the collective and cosmic totality. Key to this understanding of the person is the concept of isithunzi (Sotho-Tswana: seriti), which is sometimes translated as 'personality' and names the field of forces in which each person is constituted - a sort of affective web within which each person affects and is affected by the others. What makes each person unique is the singular set of relations particular to that person and thus 'identity' is inherently relational. Strictly speaking, then, it is true that there is no such thing as the 'individual' in this philosophy; instead, in keeping with the verbal nature described by Ramose, it is more accurate to speak only of individuation. And yet, a person is not reducible to the ontological fact of trans-individual intertwinement: while this intertwinement is indeed the ontological condition for becoming a person, each person has an obligation to realize their singularity (or 'personality') through their own activity. This is why isithunzi is 'the energy or power that both makes us ourselves and unites us in personal interaction with others' (Shutte, 1993: 55). Individuation is thus a journey to realize one's singularity insofar as it expresses the whole of the community, humanity, and Being itself. If one acts ethically in the process of individuation by striving for harmony, then one enhances oneself and others through isithunzi, while activity that disrupts harmony diminishes isithunzi not only for oneself but for all. As Gabriel Setiloane (in Battle, 2009: 117) puts it: 'It is as if each person were a magnet, creating together a complex field. Within that field, any change in the degree of magnetization, any movement of one, affects the magnetization of all.' This ontological trans-individuality imposes an immense obligation onto each person, as individuation implicates not only the collective and cosmic whole but also past and future generations, and this obligation can only be resisted with profound consequences to the self. In ubuntu philosophy, then, freedom cannot be attained through autonomy, personal choice, or the resistance to social obligations. Instead, freedom is the way in which each person becomes themselves through their relations with others: the more a person expresses their own singularity, the more they work toward the unity and harmony of the collective and comic whole (and vice versa).

It is here that $u b u n t u$ as an ontological and ethical system meets what Mabogo P. More (2004: 156) refers to as its 'political-ideological' sense as it forms the basis of socio-political action. Because human being is part of the ongoing be-ing becoming of the cosmos, the ontological principle of cosmic harmony necessarily becomes the principle of ethical action. But because ubuntu is materialized in the concrete activities of umuntu, the principle of harmony cannot be reduced to an abstract ideal of social cohesion nor can it be codified in any given moral imperative. Rather, ubuntu is inherently political because it is a perpetual struggle to bring the harmony of Being into being, which is why Ramose (2003: 279) refers to it as a 'philopraxis.' It is this 'aspirational edge' (Cornell, 2014: 139) in which the ontology of ubuntu is inseparable from political action that sets it apart from popular ontologies of interconnection in Euro-American social theory such as 'entanglement' (Barad, 2007) and 'assemblage' (DeLanda, 2006). Indeed, as Ramose (2003: 279) argues, the ontological principle of harmony inherent to ubuntu becomes a demand for justice that traverses all domains of human activity: 
Religion, politics, and law must be anchored upon the understanding of the cosmos as the continual strife for harmony. It is such anchorage which gives them authenticity and legitimacy....Peace through the concrete realization of justice is the fundamental law of ubuntu philosophy. Justice without peace is the negation of the strife towards cosmic harmony. But peace without justice is the dislocation of umuntu from the cosmic order. While ubuntu plays an immense role in the politics and religion of South Africa, its status in law is more contested. As the central value of the living customary law of the majority of the population, ubuntu was included in the 1993 Interim Constitution but removed from the final 1996 text. This has led some decolonial critics, including Ramose (2001), to argue that the new Constitution does not represent the ideals and values of the majority of the population and therefore remains an instrument of colonial hegemony. As former Constitutional Court Justice Yvonne Mokgoro (2012: 319) has contended, however, the task of decolonization is not the impossible project of recovering a pre-colonial past but of re-establishing points of contact between 'traditional' values and those of 'modernity' under 'indigenous impetus' rather than through the patterns of coloniality. Invoking the fundamental principle of ubuntu, Mokgoro (2012: 323) suggests that 'the values of ubuntu, I would like to believe, if consciously harnessed, can be central to a process of harmonizing indigenous law with the Constitution and can be integral to a new South African jurisprudence.' Indeed, through the jurisprudence of Mokgoro and some of her colleagues on Constitution Hill, ubuntu has been 'reconstitutionalized' as a justiciable principle in the supreme law of South Africa (see Cornell and Muvangua, 2012). What this demonstrates is that $u$ buntu offers not only competing notions of freedom and justice, but an alternative philosophical and political framework within which the very negotiation between Euro-American and African values can be made. This is one way that South Africa challenges the 'zero-sum game' that is presumed to exist between 'European liberal legal universalism and appeals to Africanity,' demonstrating how both the African vernacular and that of liberal democracy can be transformed through struggle for harmony, 'thereby altering the very shape and substance of postcolonial politics, of citizenship, of democracy' (Comaroff and Comaroff, 2012: 80).

\section{Toward erotic justice: sexual democracy as participatory difference}

In what ways might the ethico-ontology and the political framework of ubuntu assist in addressing the challenges posed by sexual democracy? In the spirit of the Comaroffs' (2012: 49) suggestion that theory derives from 'lived praxis,' from the ways in which real people make sense of their own everyday lives and the worlds they inhabit, I will approach this question by way of the work of Nkunzi Zandile Nkabinde. ${ }^{\text {iv }}$ Embodying the very contradictions of postcolonial sexual democracy, Zandile is a well-known lesbian activist in South Africa, a tour guide of Constitution Hill, and a sangoma or 'traditional' healer. In her memoir, Black Bull, Ancestors, and Me: My Life as a Lesbian Sangoma, Zandile tells of her struggle to find harmony between her Zulu spiritual practices and her life as a butch lesbian in the 'new' South Africa where there is often an enormous gulf between the promises of justice and the daily realities of poverty and violence. Sangomas are called by the ancestors and, through practices of ancestor engagement and natural medicine (muthi), they work to heal physical, psychic, social, and spiritual disorder. After being called as a sangoma, one undergoes an extremely difficult period of training and apprenticeship so as to learn how to draw on cosmic forces to restore harmony to individuals and communities. As Zandile (2008: 53) describes it, 'A sangoma's training is about finding balance so that we can live with respect for all life. In the training, we find our place in 
relationship with God, our ancestors, and our family. We also learn how to work with the elements of air, water, fire and earth and with the four directions.' The techniques that sangomas use in their practices are firmly grounded in the philosophy of ubuntu and, as spiritual leaders, it is often they who are responsible for the promotion of ubuntu in everyday life (see Ubuntu Township Project n.d.). Through the body of the sangoma, the living-dead continue to participate in the world of the living; however, because of isithunzi, the interconnection between people far extends Eurocentric notions of 'kinship,' and thus the ancestors with which the sangoma engages need not be direct nor even 'biological' ancestors. For her part, Zandile was aware of her heightened connection with the ancestors from a very early age, and through her training came to recognize her primary ancestor, Nkunzi, who was her great uncle. Highlighting what Gabriel Setiloane (in Battle, 1998: 116) refers to as the essentially 'psychophysical' nature of Bantu ontology, Zandile details both the psychic and corporeal transformations that this ancestor engagement entails. When Nkunzi is present, for instance, she experiences changes in her voice, eyes, musculature, and her menses even stop. In Zandile's (2008: 17) words: 'My life is not only for myself, it is also for my ancestors, especially my ancestor Nkunzi.'

For Zandile, being a lesbian is as central to her life as being a sangoma. As she narrates it, her sexuality has also been with her from an early age. Although it may be tempting to read Zandile's sexuality in terms of her trans-gender ancestral engagement, she is adamant that her sexuality is part of her singularity. And yet, she was able to realize her singularity only through the support of her ancestors: 'I feel my sexuality was with me from birth. It is not from my ancestors, but my ancestors supported me....My ancestors helped me to become who I was. They guided me knowing that I was going to grow up being the way I am' (2008: 38). While Zandile's mother and her ancestors, including Nkunzi, were accepting of her sexuality, many others were not. Indeed, several members of her family and community in her ancestral homeland in KwaZulu-Natal reacted to Zandile's sexuality with extreme hostility, accusing her of betraying Zulu tradition. During her initiation, the sangoma who trained Zandile even attempted to 'cure' her of her sexuality and, failing this, the trainer and the community elders instructed Zandile to keep her sexuality a secret. Zandile steadfastly refused, informing them that the support of her mother and her ancestors is not something that can be rejected, either by the elders or by Zandile herself. For Zandile, it would be contrary to the principle of harmony intrinsic to ubuntu to separate her life as a lesbian from her life as a sangoma. This is because, in the Bantu erotic ontology, sexuality is understood neither as a private property belonging to the individual nor simply an act that brings together atomistic individuals. Far from an autonomous sphere dislocated from the rest of a person's life, sexuality is a dimension of a person's participation in the collective and cosmic whole. As anthropologist Robert Thornton (2008: 215) explains: Through every act of sex...a person not only expresses desire and receives pleasure, but is also received into the social networks of interdependency and trust that permit the expression of one's own character. The southern African conception of the person as a creation of and through other people means that networks of social relations are the matrix out of which people achieve their sense of worth and identity. Sex is also part of this and sexual networks link not just people but also generations and, through them, nature, the environment, and the cosmos.

Zandile's erotic life, then, constitutes an intrinsic part of her personality, of the affective web that binds her to others and to the world - past, present, and future. It is therefore on the basis of ubuntu that Zandile argued that she has an ethical obligation to materialize her singularity, 
including her sexuality, in the community and it is on the basis of ubuntu that her trainer and the elders eventually recognized that they have an ethical obligation to support her.

The philopraxis of ubuntu infuses all aspects of Zandile's life as a lesbian sangoma. As she makes clear, the struggle for harmony that is fundamental to ubuntu begins with a struggle to harmonize the different aspects of the self, which radiates into a search for connection with others: 'I wanted to live my life as a sangoma and a lesbian — as one person — not divided up into pieces and I wanted to connect with other lesbian sangomas who felt the same way' (2008: 79). The ethico-ontology of ubuntu thus becomes the political ideology that motivates Zandile's work as an activist. As a participant in the Gay and Lesbian Archives (GALA), Zandile began interviewing other same-sex sangomas in the Johannesburg townships, collecting their experiences with same-sex sexuality, ritual practice, and homophobia. This project eventually led her to co-found an association of other same-sex sangomas to help end the isolation and secrecy in which many such sangomas find themselves. Because this isolation is antithetical to ubuntu, and to the practice of being a sangoma which is necessarily embedded in the collective life of the community, Zandile's organization served to give same-sex sangomas a collective space in which to cultivate their practice. Beyond this, her organization worked to challenge homophobia in the community, even standing against the powerful Congress of Traditional Leaders of South Africa, which frequently lobbies against LGBT rights in the name of protecting so-called traditional African values against the encroachment of a Eurocentric state. Pointing out that the complexities of Bantu erotic life trouble the colonially imposed sex/gender distinctions on which heterosexism is based, Zandile vociferously challenges the interpretation of same-sex sexuality as 'un-African,' insisting that 'being a lesbian is as African as being a straight person' (2008: 121). As a lesbian sangoma, Zandile can neither reject the 'traditional' values of her community in favor of the 'modern' values protected by the new Constitution nor refuse those modern values in a decolonial defense of 'indigeneity.' Instead, through her activism she uses her experience at the intersection of these conceptual worlds to create a better world for all. This struggle for harmony between worlds is best captured in Zandile's work on Constitution Hill: Working at Constitution Hill means working with a mixture of feelings every day. It is a place where there is pain and also hope, and it is a place where there is forgiveness but also scars that will always be there. This is because on one side there is sadness about our history and on the other side there is the Constitutional Court which is a place of hope. When I feel this hope in me, I feel that I have everything I need inside me to make a better world. I think my ancestors organized my job as a tour guide at Constitution Hill because it is a place where the old and the new come together in a different way. It makes me think of what my ancestor, Nkunzi said, "After I die, one of the grandchildren will take my name and follow after me and do things in a different way" (2008: 135-136). Thinking sexual democracy through $u b u n t u$ would thus problematize many of the assumptions of Euro-American theory. A politics based on notions of autonomous selfexpression and resistance to social obligations that are central to both the liberal and queer paradigms are not acceptable within an ethico-ontology of the person as embedded within a web of relations that is the very condition of individual, collective, and cosmic becoming. From this point of view, it is easy to understand why some African 'traditional' leaders object to the idea that an individual's 'sexual identity' is grounds for extricating oneself from this collective and cosmic picture. This is why, as South African activist Mikki van Zyl (2015: 149) has suggested, theorizing global sexual politics would require that the exclusive focus on 'individual subjects as targets of discipline in justice and governance' in Euro-American theory be supplemented by an 
African relational perspective that focuses on 'maintaining an equilibrium in the social fabric.' For van Zyl, this entails a shift away from the framework of 'sexual rights' to one of 'erotic justice' that is capable of considering both erotic life beyond individualized sexual identities and acts as well as justice beyond the limited framework of rights. 'Erotic justice,' writes van Zyl (2015: 148), 'resonates with the values of dignity and equality that surely we all yearn for in those aspects of our lives that are life-affirming-love, care, connection with others, children, and our general health and well-being.' As Zandile's work demonstrates, cultivating this more capacious politics of erotic justice in a globalizing world would require 'find[ing] synergies between African histories of queer sexualities, values of communalism, and the power of the human rights paradigm' (van Zyl, 2015: 154). This would call for queer-decolonial theory whose task is not merely to deconstruct the Euro-American onto-epistemologies of 'sexuality' or of 'democracy' but, to borrow from Justice Mokgoro, to re-establish new points of connection with the landmarks of 'sexual democracy' under African, or Southern, impetus.

The point here has not been to offer ubuntu as an alternative all-encompassing framework, but to demonstrate how the global project of sexual democracy might be radically transformed through queer theory from the South. Rethinking such a project as the struggle for erotic justice would require an alignment of sexual politics with larger struggles for economic, health, and environmental justice. It would also both require and enable the framework of sexual democracy to be pushed far beyond the very limited Euro-American conceptions of democracy as recognition and the expression of choice by drawing on the robust African tradition of participatory democracy. If the struggle for justice is embedded in the very fabric of everyday life, every person has a responsibility to participate in the ongoing creation of a collectively shared world. This is what D. A. Masolo (2004: 495) calls 'participatory difference,' in which each person expresses their difference by making a difference in the world. And as the Comaroffs (2012: 88) argue, some of the most novel experiments in democracy in the world today happen when this African understanding of participatory difference meets liberal juridicallegal frameworks, pushing liberalism to its limits by 'forcing it to fashion a jurisprudence' that can deal with difference 'without criminalizing it.' In this way, Africans are decolonizing democracy by finding a way beyond the dilemma that forces them to choose between 'a highly un-African political order, wherein the body politic is composed of autonomous, individualized, rights-bearing citizens' on the one hand and 'an "indigenous" alternative, usually characterized as anti-modern, ethnically based, patriarchal, traditionalist, customary, communalist, clientalist, and authoritarian' on the other (Comaroff and Comaroff, 2012: 113). Occupying the interstices of these worlds, African queers - in both the North and South - must navigate this path every day, when finding ways of negotiating between competing values is often a matter of life and death. Following their lead would enable sexual democracy to be rebuilt from the ground up by cultivating a queer politics of participatory difference in the global struggle for erotic justice. Thus, as we struggle to make sense of sexuality in the context of a crisis in democracy, queer theory from the South is what the Comaroffs (2012: 48) might call one way in which 'EuroAmerica ought to evolve more rapidly toward Africa.'

\section{References}

Barad K (2007) Meeting the Universe Halfway: Quantum Physics and the Entanglement of Matter and Meaning. Durham NC: Duke University Press. Battle M (2009) Ubuntu: I in You and You in Me. New York: Seabury Books. Bhambra G (2014) Connected Sociologies. London: Bloomsbury. 
Butler J et al (2000) Contingency, Hegemony, Universality: Contemporary Dialogues on the Left. New York: Verso.

Butler J (2008) Sexual politics, torture, and secular time. The British Journal of Sociology 59(1): $1-23$.

Chakrabarty D (2000) Provincializing Europe: Postcolonial Thought and Historical Difference. Princeton: Princeton University Press.

Comaroff J and Comaroff JL (2012) Theory from the South: How Euro-America Is Evolving Toward Africa. Boulder: Paradigm Press

Connell R (2007) Southern Theory: Social Science and the Global Dynamics of Knowledge. Cambridge: Polity Press.

Cornell D (2008) Moral Images of Freedom: A Future for Critical Theory. Lanham: Rowman \& Littlefield.

Cornell D (2014) Law and Revolution in South Africa: uBuntu, Dignity, and the Struggle for Constitutional Transformation. New York: Fordham University Press.

Cornell D and Muvangua N (2012) Ubuntu and the Law: African Ideals and Post-Apartheid Jurisprudence. New York: Fordham University Press.

Cornell D and Seely S (2016) The Spirit of Revolution: Beyond the Dead Ends of Man. Cambridge: Polity Press.

Currier A and Migraine-George T (2016) Queer studies/African studies: an (im)possible transaction? GLQ: A Journal of Gay and Lesbian Studies 22(2): 281-305.

De Cauwer S, ed. (2018) Critical Theory at a Crossroads: Conversations on Resistance in Times of Crisis. New York: Columbia University Press.

De Sousa Santos B (2014) Epistemologies of the South: Justice Against Epistemicide. London:

Routledge.

DeLanda M (2006) A New Philosophy of Society: Assemblage Theory and Social

Complexity. London: Continuum.

Ekine S and Abbas H, eds. (2013) Queer African Reader. Cape Town: Pambazuka Press.

Fassin E (2010) National identities and transnational intimacies: sexual democracy and the politics of immigration in Europe. Public Culture 22(3): 507-529.

Gevisser M and Cameron E, eds. (1995) Defiant Desire: Gay and Lesbian Lives in South Africa.

London: Routledge.

Giametta C (2017) The Sexual Politics of Asylum. London: Routledge.

Hendriks T (2018) 'Erotiques Cannibales': a queer ontological take on desire from urban Congo. Sexualities 21(5-6): 853-867.

Hoad N (2007) African Intimacies: Race, Homosexuality, and Globalization. Minneapolis:

University of Minnesota Press.

Hoad N, Martin K, and Reid G, eds. (2005) Sex and Politics in South Africa. Lansdowne: Double Storey Books.

Holbraad M and Pedersen MA (2017) The Ontological Turn: An Anthropological Exposition. Cambridge: Cambridge University Press.

Inglehart R and Norris P (2003) The true clash of civilizations. Foreign Policy 135: 62-70.

Kant I (1998) Critique of Pure Reason (translated from the German by P Guyer and A Wood).

Cambridge: Cambridge University Press.

Latour B (2002) War of the Worlds: What About Peace? Chicago: Prickly Paradigm Press.

Luciano D and Chen M, eds. (2015) Queer Inhumanisms. A special issue of GLQ: A Journal of Gay and Lesbian Studies 21 (2-3). 
Lugones M (2007) Heterosexualism and the modern/colonial gender system. Hypatia 22(1): 186209.

Luibhéid E (2002) Entry Denied: Controlling Sexuality at the Border. Minneapolis: University of Minnesota Press.

Mahmood S (2005) The Politics of Piety: The Islamic Revival and the Feminist Subject. Princeton NJ: Princeton University Press.

Maldonado-Torres N (2007) On the coloniality of Being: contributions to the development of a concept. Cultural Studies 21(2-3): 240-270.

Masolo DA (2004) Western and African Communitarianism: A Comparison. In: Wiredu K (ed.) A Companion to African Philosophy. Oxford: Blackwell.

Massad J (2007) Desiring Arabs. Chicago: University of Chicago Press.

Matabeni Z, ed. (2014) Reclaiming Afrikan: Queer Perspectives on Sexual and Gender Identities. Cape Town: Modjaji Books.

Mikdashi M and Puar J (2016) Queer theory and permanent war. GLQ: A Journal of Gay and Lesbian Studies 22(2): 215-222.

Mohanty CT (2003) Feminism Without Borders: Decolonizing Theory, Practicing Solidarity. Durham: Duke University Press.

Mokgoro Y (2012) Ubuntu and the law in South Africa. In: Cornell D and Muvangua N (eds.) Ubuntu and the Law: African Ideals and Post-Apartheid Jurisprudence. New York: Fordham University Press, pp. 317-323.

More MP (2004) Philosophy in South Africa after and under apartheid. In: Wiredu K (ed.) $A$ Companion to African Philosophy. Oxford: Blackwell, pp. 149-160.

Morgensen SL (2011) Spaces Between Us: Queer Settler Colonialism and Indigenous Decolonization. Minneapolis: University of Minnesota Press.

Munro B (2012) South Africa and the Dream of Love to Come: Queer Sexuality and the Struggle for Freedom. Minneapolis: University of Minnesota Press.

Nkabinde NZ (2008) Black Bull, Ancestors and Me: My Life as a Lesbian Sangoma. Sunnyside:

Jacana Media.

Onapajo $\mathrm{H}$ and Isike $\mathrm{C}$ (2016) The global politics of gay rights: the straining of relations between the West and Africa. Journal of Global Analysis 6(1): 21-45.

Penny J (2014) After Queer Theory: The Limits of Sexual Politics. New York: Pluto Press.

Puar J (2007) Terrorist Assemblages: Homonationalism in Queer Times. Durham, NC:

Duke University Press.

Puar J (2017) The Right to Maim: Debility Capacity Disability. Durham: Duke University Press. Quijano A (2010) Coloniality and modernity/rationality. In: Mignolo W and Escobar A (eds.) Globalization and the Decolonial Option. London: Routledge, pp. 22-31.

Ramose MB (2001) An African perspective on justice and race. Polylog: Forum for Intercultural Philosophy 3. https://them.polylog.org/3/frm-en.htm

Ramose MB (2003) The philosophy of ubuntu and ubuntu as philosophy. In: Coetzee PH and Roux APJ (eds.) The African Philosophy Reader. London: Routledge, pp. 270-280.

Richardson D (2017) Sexuality and Citizenship. Cambridge: Polity Press.

Sabsay L (2016) The Political Imaginary of Sexual Freedom: Subjectivity and Power in the New Sexual Democratic Turn. London: Palgrave Macmillan.

Sedgwick EK (1990) Epistemology of the Closet. Berkeley: University of California Press.

Shutte A (1993) Philosophy for Africa. Cape Town: University of Cape Town Press.

Tamale S, ed. (2015) African Sexualities: A Reader. Cape Town: Pambazuka Press. 
Thomas G (2007) The Sexual Demon of Colonial Power: Pan-African Embodiment and Erotic Schemes of Empire. Indianapolis: Indiana University Press. Thornton RJ (2008) Unimagined Community: Sex, Networks, and AIDS in Uganda and South Africa. Berkeley: University of California Press.

Ubuntu Township Project (n.d.) 'Ubuntu in everyday life'. Unpublished interview dossier on file with author.

Van Zyl M (2015) Taming monsters: theorizing erotic justice in Africa. Agenda 29(1): 147-154. Viveiros de Castro E (2015) The Relative Native: Essays in Indigenous Conceptual Worlds. Chicago: Hau. Weston K (1993) Lesbian/gay studies in the house of anthropology. Annual Review of Anthropology 22: 239-267.

Wiegman R and Wilson E, eds. (2015) Queer theory without antinormativity. A special issue of differences.

\footnotetext{
i The material in this essay has been developed in different contexts over several years and owes much to many people. I particularly thank Drucilla Cornell for first introducing me to South Africa and ubuntu, in theory and in practice. I also thank a number of institutions and people who have given space for these ideas to be developed, supported and critiqued: The Ubuntu Project, The Department of Jurisprudence at the University of Pretoria, The Department of Religion at the University of Johannesburg, the Wits Institute for Social and Economic Research, the Gay and Lesbian Archives (GALA) in Johannesburg, and many academics, activists, and strangers who have discussed South African (sexual) politics with me and shown me ubuntu. I also thank the editor Agnes Skamballis for her patience and two anonymous reviewers for their helpful comments.

ii It is beyond the limited scope of this essay to document or theorize the highly complicated development of 'sexual democracy' in South Africa, its contested possibilities and realities, and the integral role a certain notion of sexual liberty has played, and continues to play, in South Africa's democratic imaginary. For important historical and theoretical accounts of this development, see Gevisser and Cameron (1995); Hoad, Martin and Reid (2005); Hoad (2007); and Munro (2012).

iii For important texts on queer theory in Africa, or African queer theory, see Currier and Migraine-George (2016); Erkine and Abbas (2013); Matabeni (2014); and Tamale (2015)

iv Sadly, I was informed on a visit to the Gay and Lesbian Archives in Johannesburg in May 2019 that Nkunzi passed away in 2018 and in the decade since the publication of Black Bull, had begun living as a transman, having planned to write another memoir about that transition. Given that my discussion of Nkunzi's work is taken entirely from the Black Bull memoir, within which it is Nkunzi's identity as a lesbian sangoma that is absolutely centraland because Nkunzi never got the chance to publicly narrate his transition himself-I will continue to use the feminine pronoun when discussing the book. Also, given Nkunzi's engagement with the ancestors, it feels wrong to refer to him in the past tense here, and thus I have kept the discussion of him in the text above in the present tense.
} 